\title{
A perspective of the relationship of serum HBV DNA and HBsAg apportioned by the same hepatic parenchyma cell volume with inflammation in the natural history of chronic hepatitis $B$
}

\author{
Lei Tan ${ }^{1}$, Ze-Qian Wu ${ }^{2,3}$, Chang Zhao ${ }^{4}$, Shu-Ru Chen ${ }^{2,3}$, Pei-Pei Wang ${ }^{2,3}$, Zhi-Liang Gao ${ }^{2,3}$, \\ Dong-Ying $\mathrm{Xie}^{2,3}$, Kun-Peng $\mathrm{Hu}^{5}$, Zhi-Shuo $\mathrm{Mo}^{2,3}$
}

${ }^{1}$ Department of Medical Ultrasonic, The Third Affiliated Hospital of Sun Yat-sen University, Guangzhou, China; ${ }^{2}$ Department of Infectious Diseases, The Third Affiliated Hospital of Sun Yat-sen University, Guangzhou, China; ${ }^{3}$ Key Laboratory of Topical Disease Control, Sun Yatsen University, Ministry of Education, Guangzhou, China; ${ }^{4}$ Department of Pathology, The Third Affiliated Hospital of Sun Yat-sen University, Guangzhou, China; ${ }^{5}$ Department of General Surgery, The Third Affiliated Hospital of Sun Yat-sen University-Lingnan Hospital, Guangzhou, China Contributions: (I) Conception and design: L Tan, ZQ Wu, ZS Mo; (II) Administrative support: ZL Gao, DY Xie; (III) Provision of study materials or patients: PP Wang; (IV) Collection and assembly of data: C Zhao, SR Chen; (V) Data analysis and interpretation: ZQ Wu, KP Hu; (VI) Manuscript writing: All authors; (VII) Final approval of manuscript: All authors.

Correspondence to: Prof. Zhi-Shuo Mo, MM. Third Affiliated Hospital of Sun Yat-sen University, 600 Tianhe Road, Guangzhou 510630, China. Email: mozhsh@mail.sysu.edu.cn; Prof. Kun-Peng Hu, MD. 2693 Kaichuang Road, Guangzhou 510700, China. Email: hfjjpj@163.com.

Background: This study aimed to investigate the dynamic changes of serum HBV DNA and hepatitis B surface antigen (HBsAg) titers apportioned by the same hepatic parenchyma cell volume (HPCV) at different liver histological inflammation grades in the natural history of chronic hepatitis B (CHB).

Methods: The serum HBV DNA and HBsAg titers were detected by real-time polymerase chain reaction and electrochemiluminescence, separately, in CHB patients without any treatment. The serum HBV DNA levels and HBsAg titers apportioned by the same HPCV were figured out based on sphere geometry theory. In addition, the differences of HBV DNA levels and HBsAg titers apportioned by the same HPCV in different liver inflammation grades were further assessed based on statistical analysis.

Results: There was no difference of serum HBV DNA levels or HBsAg titers before apportioned by the same HPCV in liver inflammation grades 1-4, but significant differences were observed after apportion in CHB patients (HBV DNA: $\mathrm{P}=0.101$; HBsAg: $\mathrm{P}=0.211$ \& HBV DNA apportioned by HPCV: $\mathrm{P}<0.001$; HBsAg apportioned by HPCV: $\mathrm{P}<0.001)$. No correlation was observed between HBV DNA levels and liver inflammation grades $(\mathrm{r}=0.083, \mathrm{P}=0.186)$, or between HBsAg titers and liver inflammation grades $(\mathrm{r}=0.083$, $\mathrm{P}=0.078)$. A significant correlation was observed between HBV DNA levels apportioned by HPCV and liver inflammation grades $(\mathrm{r}=0.249, \mathrm{P}<0.001)$, and obvious correlation of HBsAg titers apportioned by HPCV and liver inflammation grades was also found in CHB patients $(\mathrm{r}=0.554, \mathrm{P}<0.001)$.

Conclusions: These results suggest that the levels of serum HBV DNA and HBsAg apportioned by the same HPCV are correlated with the severity of liver histological inflammation grade in the natural history of CHB.

Keywords: Liver inflammation grades; hepatic parenchyma cell volume; serum HBV DNA levels; serum HBsAg levels

Submitted Mar 13, 2020. Accepted for publication Aug 28, 2020.

doi: 10.21037/apm-20-635

View this article at: http://dx.doi.org/10.21037/apm-20-635 


\section{Introduction}

Chronic hepatitis B virus (HBV) infection remains an inconvenient public health burden, and the major epidemic areas of HBV infection among adults are Asia and Africa. In the course of natural infection, the development of chronic hepatitis B (CHB) leads to progressive liver fibrosis, cirrhosis, and an increased risk of liver cancer (1). Despite the existence of effective prevention and treatment interventions, $\mathrm{HBV}$ infection still causes nearly over 500,000 people to die around the world each year (2). During the viral infection, the majority of patients could remain in the phase of immune tolerance for a long time. In some $\mathrm{CHB}$ patients, after the disease enters the immune clearance phase, the continual aggravation of hepatocyte injury mediated by HBV infection activates would cause the development of liver inflammation and fibrosis (3). The progression of hepatic inflammation and fibrosis will lead to hepatocellular necrosis and the reduction of hepatic parenchyma cells gradually. The more accumulation of inflammation and fibrosis caused by a viral infection, the less hepatic parenchyma cell volume (HPCV) can be provided to HBV replication $(4,5)$. In clinical practice, the replication of $\mathrm{HBV}$ is usually assessed by viral DNA load and HBV surface antigen (HBsAg) in serum $(6,7)$, and the decline of these two clinical parameters was often observed in CHB patients with hepatic fibrosis in different degree $(8,9)$. However, the dynamic changes of serum HBV DNA and HBsAg levels in different liver inflammation grades are not well clear. Furthermore, whether the change in serum HBV DNA and HBsAg level during different liver inflammation phase is a true reflection of HBV replication level in HPCV in the natural history of $\mathrm{CHB}$ needs to be assessed. In the study, we detected the dynamic expression pattern of serum HBV DNA as well as HBsAg titers apportioned by the same HPCV at liver histological inflammation grades 1, 2, 3, and 4. It helps to clarify the pathogenesis and natural history of $\mathrm{CHB}$, and is more helpful in monitoring, following up, or making antiviral therapy of $\mathrm{CHB}$.

We present the following article in accordance with the MDAR reporting checklist (available at http://dx.doi. org/10.21037/apm-20-635).

\section{Methods}

\section{Patients}

An across-sectional study was performed in $254 \mathrm{CHB}$ patients, including 210 male and 44 female with a median age of 36.7 years (min. 10, max. 67 years), were enrolled before any anti-HBV therapies, in the Department of Infectious Disease, the Third Affiliated Hospital of Sun Yat-sen University, Guangzhou, China, between 2008 and 2012. Hepatic steatosis, nonalcoholic steatohepatitis (NASH), or the patients with severe alcohol consumption that influenced serum HBV DNA levels, HBsAg titers, or liver inflammation grades were excluded. Furthermore, the superinfection or coinfection of hepatitis A, C, D, E, and human immunodeficiency virus (HIV) had been excluded by texting the serum markers of those pathogens with Enzyme-Linked Immunosorbent Assay (ELISA).

\section{Ethics statement}

This work was approved by the ethical committee of the Third Affiliated Hospital of Sun Yat-sen University (the ethical number: [2018]02-429-01). All 254 CHB patients in our retrospective investigation had been informed of possible complications with liver biopsies clearly before the invasive operation, and informed consent forms had been signed. All patients' data we used were fully anonymized. None of the authors of this study participated in the liver biopsy for the assessment of the degree of inflammation in $\mathrm{CHB}$ patients. This study has been performed in accordance with the principles of Declaration of Helsinki (as revised in 2013).

\section{Serum HBV DNA levels and serum HBsAg titers}

HBV DNA levels were determined by real-time polymerase chain reaction (PCR) (Da-an Gene Co., Guangzhou, PR China). The lower limit of detection is $100 \mathrm{IU} / \mathrm{mL}$. HBsAg titers were performed with Elecsys (Roche Diagnostics $\mathrm{GmbH}$, Mannheim). The judgment standards are stated as follows: reference ranges of $\mathrm{HBsAg}$, anti-HBs, $\mathrm{HBeAg}$, anti-HBe and anti-HBc are $<1.0$ (cut off index, COI), 0-10 IU/L, <1.0 COI, >1.0 COI and >1.0 COI, respectively. The test results of COI values read positive within the reference ranges while negative without it.

\section{Liver histopathological diagnosis and measurements of hepatic fibrosis proportion}

Liver biopsies in these 254 chronic hepatitis B patients were performed by automatic gun mating $16 \mathrm{G}$ needle and were guided by Esaote AU4 color Doppler system (Esaote, USA). The obtained section of each sample was about 
20 millimeters in length. The biopsy specimens were fixed with Bouin's solution and embedded in paraffin. Then stain them with Hematoxylin-Eosin and Masson's trichrome, respectively. Liver histological inflammation grades and hepatic fibrosis stages were diagnosed according to Desmet VJ chronic hepatitis classification by liver pathologists in our hospital $(10,11)$. Using a JVC-KY-F30B3-CCD lens (Japan) and Zeiss Axiotron microscope (Carl Zeiss AG, Germany), the measurements of hepatic fibrosis proportion were assessed with an automatic imaging analysis system (Kontron IBAS 2.5, Germany). Images of each microscope were magnified 400 times. Five fields of each vision were randomly selected from four corners and center respectively on a section to average fibrous percentages in different fibrosis stages. According to the results of automatic imagine analysis, the proportions of hepatic fibrosis were $8.31 \% \pm 2.90 \%, 11.43 \% \pm 2.76 \%, 14.97 \% \pm 5.88 \%$ and $20.73 \% \pm 4.44 \%$ in hepatic fibrosis stages $1,2,3$ and 4 , respectively.

\section{Calculation of HPCV by the fibrosis proportion in different hepatic inflammation grades}

The calculation of serum HBV DNA and HBsAg levels apportioned by the same HPCV in different liver inflammation grades was described previously (11). In short, the serum HBV DNA and HBsAg levels apportioned by $\mathrm{HPCV}$ in different liver fibrosis grades were equal to the serum HBV DNA and HBsAg level in each patient with the same liver histological necroinflammation grade divided by the percentage of HPCV of their liver fibrosis stage.

According to the ken principles of the microscope, $100 \%$ rotundity areas of each vision consist of different proportions of the hepatic parenchyma area and different proportions of the hepatic fibrosis area approximately. Based on automatic imaging analysis, the proportions of hepatic parenchyma cell areas are equal to $100 \%$ rotundity area of each vision minus hepatic fibrosis areas, calculated as $91.69 \%(100-8.31 \%), 88.57 \%(100-11.43 \%), 85.03 \%$ (100-14.97\%), and $79.27 \%$ (100-20.73\%) in hepatic fibrosis stages $1,2,3$, and 4 , respectively.

Because the rotundity area formula is $A=\pi R^{2}$, radii (R) of internal smaller rotundity hepatic parenchyma cell area is equal to the root of the ratio of internal smaller rotundity hepatic parenchyma cell area (A) to pi $(\pi)$, namely $\mathrm{R}=\sqrt{A / \pi}$. The radii of the rotundity area of hepatic parenchyma cell area in hepatic fibrosis stages 1, 2, 3, and 4 is $\sqrt{91.69 \% / 3.14}=0.5404, \sqrt{88.57 \% / 3.14}=0.5311$, $\sqrt{85.03 \% / 3.14}=0.5204$, and $\sqrt{79.27 \% / 3.14}=0.5023$, respectively. Furthermore, as the formula of sphere volume $(\mathrm{V})$ is $4 / 3 \pi \mathrm{R}^{3}$, the three-dimensional sphere HPCV volume is $\mathrm{V} 1=4 / 3 \pi \mathrm{R} 1^{3}=4 / 3 \times 3.14 \times 0.54043=66.07 \%, \mathrm{~V} 2=4 / 3 \pi \mathrm{R} 2^{3}=$ $4 / 3 \times 3.14 \times 0.53113=62.72 \%, \mathrm{~V} 3=4 / 3 \pi \mathrm{R} 3^{3}=4 / 3 \times 3.14 \times 0.52043$ $=59.00 \%$ and $\mathrm{V} 4=4 / 3 \pi \mathrm{R} 4^{3}=4 / 3 \times 3.14 \times 0.50233=53.06 \%$, in hepatic fibrosis stages 1 to 4 , respectively. Figure 1 was shown as the calculation process. Table 1 showed the results of serum HBV DNA and HBsAg before and after being apportioned by the same HPCV in different inflammation stages, which was were equal to the serum HBV DNA and HBsAg level with the same liver fibrosis stages as mentioned above.

\section{Statistical analysis}

Statistical analyses were performed using SPSS 20.0 software. The comparisons in serum HBV DNA and HBsAg levels before and after apportioned by the same HPCV in liver inflammation grades 1 to 4 were assessed with ANOVA test. $\mathrm{P}$ values $<0.01$ were considered significant. The correlation of serum HBV DNA/HBsAg levels with liver inflammation grades was investigated using Pearson analysis.

\section{Results}

\section{Dynamic changes of serum HBV DNA/HBsAg and serum HBV DNA/HBsAg apportioned by the same HPCV indifferent inflammation grades}

As the results showed in Table 1, no significant differences were found in the dynamics of serum HBV DNA, or HBsAg titers among different liver inflammation grades in CHB patients. However, the severer the inflammation was, the higher the serum HBV DNA and HBsAg titers apportioned by the same HPCV were observed.

\section{Statistical analysis of serum HBV DNA/HBs Ag, serum HBV DNA/HBsAg apportioned by the same HPCV in different inflammation grades}

There were no differences in serum HBV DNA levels or HBsAg titers in liver inflammation grades from 1 to 4 . ( $\mathrm{F}=2.098, \mathrm{P}=0.101$ or $\mathrm{F}=1.517, \mathrm{P}=0.211$, respectively), but the significant differences were found in serum HBV DNA levels or HBsAg titers apportioned by the same HPCV in different hepatic inflammation grades $(\mathrm{F}=6.375, \mathrm{P}<0.001$ 

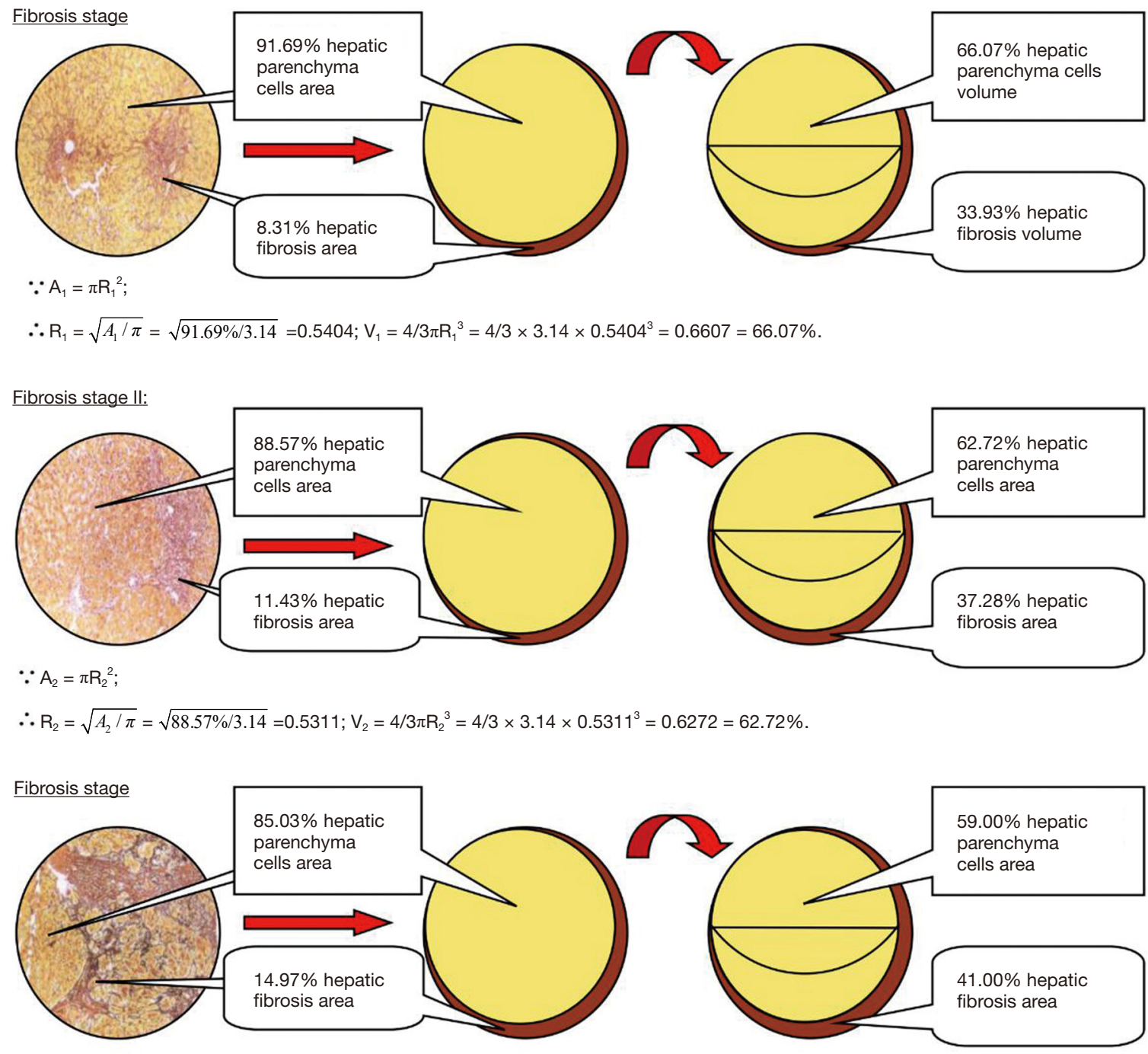

$\because \mathrm{A}_{3}=\pi \mathrm{R}_{3}^{2}$

$\therefore \mathrm{R}_{3}=\sqrt{A_{3} / \pi}=\sqrt{85.03 \% / 3.14}=0.5204 ; \mathrm{V}_{3}=4 / 3 \pi \mathrm{R}_{3}^{3}=4 / 3 \times 3.14 \times 0.5204^{3}=0.5900=59.00 \%$.

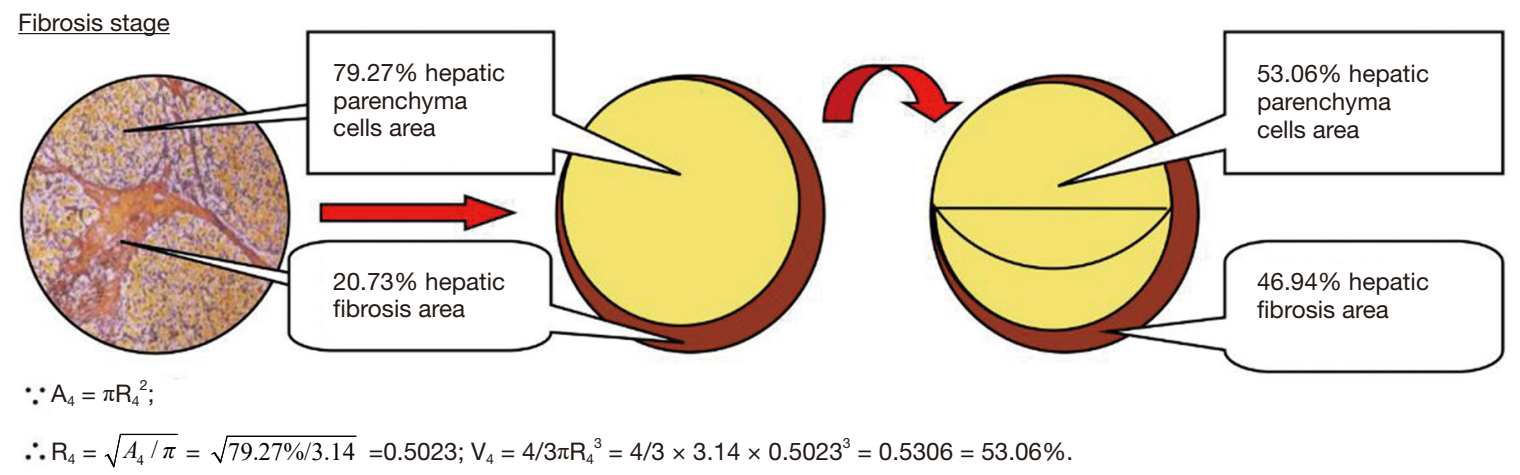

Figure 1 Sketch map of calculation of hepatic parenchyma cell volume (HPCV) in liver inflammation grades 1 to 4. 
Table 1 Serum HBV DNA and HBsAg, serum HBV DNA and HBsAg apportioned by the same HPCV in different inflammation grades

\begin{tabular}{lccccc}
\hline $\begin{array}{l}\text { Liver inflammation } \\
\text { grades }\end{array}$ & $\begin{array}{c}\text { Case } \\
\text { number }\end{array}$ & $\begin{array}{c}\text { Serum HBVDNA } \\
\text { (log10lU/mL) }\end{array}$ & $\begin{array}{c}\text { Serum HBV DNA } \\
\text { apportioned by the same } \\
\text { HPCV (log10lU/mL) }\end{array}$ & $\begin{array}{c}\text { Serum HBsAg } \\
\text { (log10COI) }\end{array}$ & $\begin{array}{c}\text { Serum HBsAg apportioned } \\
\text { by the same HPCV } \\
(\text { log10COI) }\end{array}$ \\
\hline G1 & 49 & $4.65 \pm 2.27$ & $7.09 \pm 3.46$ & $3.55 \pm 0.42$ & $5.42 \pm 0.71$ \\
G2 & 91 & $5.49 \pm 1.94$ & $8.70 \pm 3.07$ & $3.65 \pm 0.34$ & $5.80 \pm 0.61$ \\
G3 & 63 & $5.14 \pm 1.99$ & $8.88 \pm 3.39$ & $3.62 \pm 0.46$ & $6.30 \pm 0.86$ \\
G4 & 51 & $5.43 \pm 1.80$ & $9.92 \pm 3.27$ & $3.71 \pm 0.30$ & $6.81 \pm 0.72$ \\
\hline
\end{tabular}

Table 2 Statistical analysis of serum HBV DNA and HBsAg, serum HBV DNA and HBsAg apportioned by the same HPCV in different inflammation grades (P value)

\begin{tabular}{lcccc}
\hline & Serum HBV DNA & $\begin{array}{c}\text { Serum HBV DNA apportioned by } \\
\text { the same HPCV }\end{array}$ & Serum HBsAg & $\begin{array}{c}\text { Serum HBsAg apportioned } \\
\text { by the same HPCV }\end{array}$ \\
\hline G1\&G2 & 0.019 & 0.006 & 0.136 & 0.003 \\
G1\&G3 & 0.200 & 0.004 & 0.295 & $<0.001$ \\
G1\&G4 & 0.052 & $<0.001$ & 0.038 & $<0.001$ \\
G2\&G3 & 0.286 & 0.737 & 0.690 & $<0.001$ \\
G2\&G4 & 0.866 & 0.035 & 0.386 & $<0.001$ \\
G3\&G4 & 0.440 & 0.094 & 0.249 & $<0.001$ \\
\hline
\end{tabular}

and $\mathrm{F}=37.254, \mathrm{P}<0.001$, respectively) (Table 2).

\section{Pearson correlations of serum $\mathrm{HBV}$ DNA/HBs $\mathrm{Ag}$ or HBV DNA/HBsAg apportioned by the same HPCV with inflammation grades}

As shown in Figure 2, both the serum HBV DNA levels and HBsAg apportioned by the same HPCV were shown to have a strong positive correlation with liver inflammation grades (HBV DNA apportioned by the same HPCV: $\mathrm{R}=0.249, \mathrm{P}<0.001 ; \mathrm{HBsAg}$ apportioned by the same HPCV: $\mathrm{R}=0.554, \mathrm{P}<0.001$ ), while no significant correlation was found before apportion (HBV DNA: $\mathrm{R}=0.083, \mathrm{P}=0.186$; HBsAg: $\mathrm{R}=0.083, \mathrm{P}=0.078$ ).

\section{Discussion}

Until now, serum HBV DNA levels and HBsAg titers are the main and classic markers in monitoring viral replication, and evaluating antiviral therapeutic effect in patients with chronic HBV infection $(12,13)$. There is a good positive correlation of intrahepatic cccDNA levels with HBV DNA and HBsAg levels released into peripheral blood, and both serum HBV DNA and HBsAg can be affected by virus replication activity (14-16). However, the dynamic changes of serum HBV DNA and HBsAg in CHB patients with different stages of viral infection are not well clear.

Injury of hepatocytes is typically caused by liver inflammation activity, accompanied by fibrosis formation. Progress of liver inflammation is usually accompanied by the accumulation of hepatic fibrosis. It means that hepatic parenchyma cell volume is affected, and efficient hepatic cell quantity is shrinking with the development of liver inflammation and fibrosis. Undoubtedly, the less hepatic parenchyma cells can be provided to HBV replication, the less serum HBV DNA and HBsAg can be released into the circulation. As some studies showed, both serum HBV DNA levels and HBsAg titers decline as liver inflammation and fibrosis progress in HBeAg positive CHB (17-20). But other researches indicated that both serum HBV DNA levels and HBsAg titers are independent of liver inflammation and fibrosis $(21,22)$. Nevertheless, the impact of inflammation on HPCV was not taken into consideration by the studies above. Whether the HPCV could affect viral replication and the level of serum HBV DNA levels and HBsAg titers is not well clear. Therefore, it is necessary to 

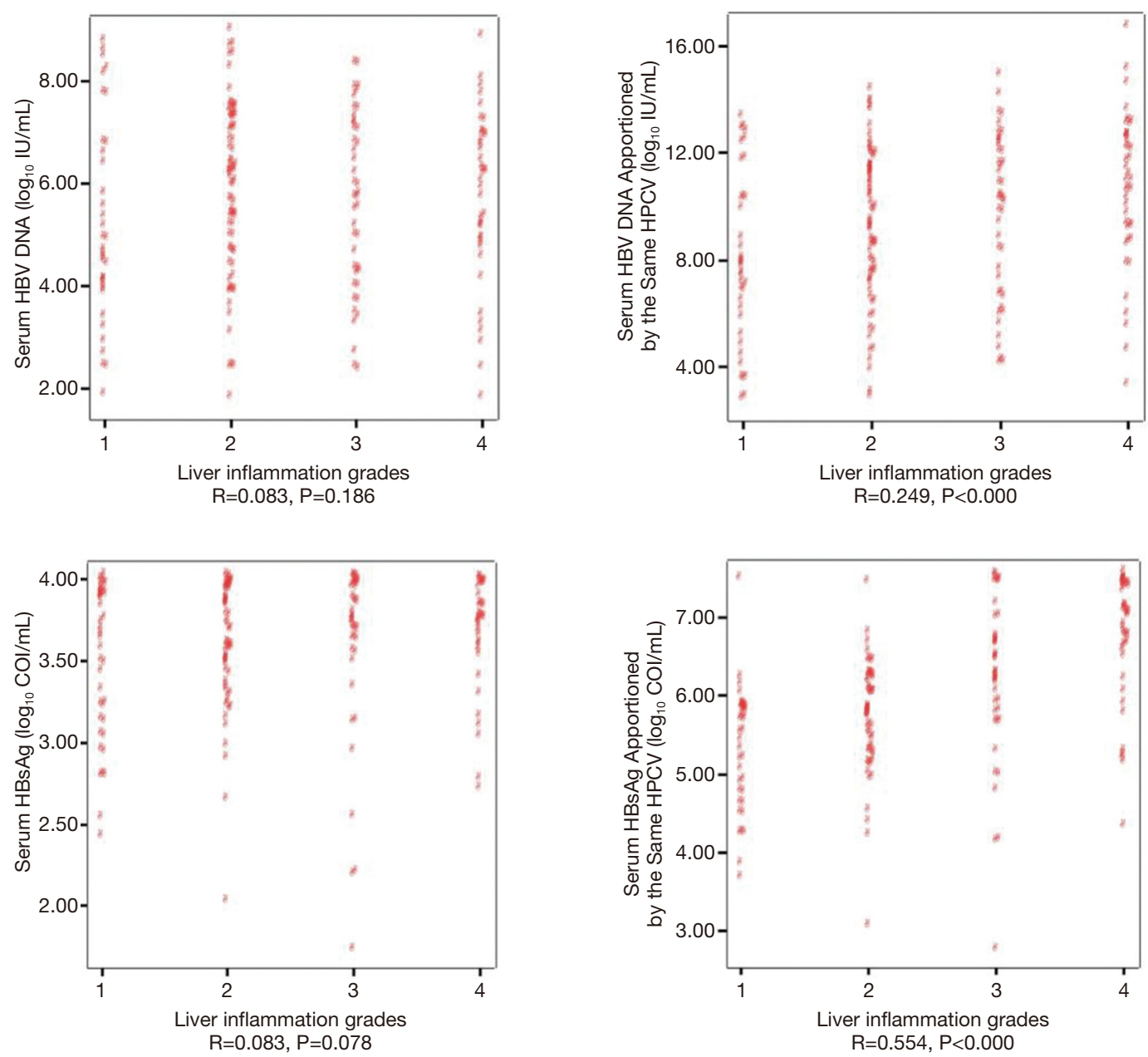

Figure 2 Pearson correlations of serum HBV DNA/HBsAg or HBV DNA/HBsAg apportioned by the same HPCV and inflammation grades.

figure out the dynamic expression patterns of serum $\mathrm{HBV}$ DNA and HBsAg levels apportioned by the same HPCV in different liver inflammation grades.

Current studies indicated that the expression of HBV DNA and HBsAg is declined in CHB patients with hepatic fibrosis $(8,9)$. However, the previous study showed that the decrease in HBV DNA level from liver fibrosis stage from 1 to 4 is not a true reflection of a decline of viral replication level in hepatic parenchyma cells. HBV DNA released by the same HPCV in hepatic fibrosis stages 1-4 is similar during the natural course of CHB $(11,23)$. The result of these studies inspired us that "the natural decline" of serum HBV DNA levels, as well as HBsAg titers in the natural history of $\mathrm{CHB}$, does not represent the reduction of viral replication nor the easing of liver inflammation. This is a new understanding of "natural decline" of serum HBV
DNA and HBsAg titers in the natural history of CHB from a pathological perspective, and it reminds us that we should be cautious about these CHB patients whose serum HBV DNA levels and (or) HBsAg titers monitored "declining" naturally. We should be aware of the impact of liver inflammation and companied hepatic fibrosis on HPCV, where HBV replicates.

In the study, we mainly focus on exploring the effect of hepatic inflammation on the serum HBV DNA and HBsAg titers apportioned by the same HPCV. Consistent with previous reports (21), no significant differences in inflammation grades 1-4 were found, and these results indicated that serum HBV DNA levels and HBsAg titers are independent of liver inflammation grades in CHB patients. However, after serum HBV DNA levels and HBsAg titers were apportioned by the same HPCV at different liver 
histological inflammation grades, with the increase of hepatic inflammation, the expression of HBV serum DNA and HBsAg were elevated. The above results suggest that inflammation could stimulate the release of HBV DNA and HBsAg from the same HPCV during the natural course of CHB. Furthermore, although HBV DNA and HBsAg were not associated with liver inflammation grades, a strong positive correlation with liver inflammation grades were observed with the levels of serum HBV DNA and HBsAg apportioned by the same HPCV.

In our study, only a limited number of patients were enrolled to explore the relationship of serum $\mathrm{HBV}$ DNA and HBsAg apportioned by the same HPCV with inflammation in CHB patients. To better understand the effect of inflammation on the level of serum HBV DNA as well as HBsAg apportioned by the same HPCV, a large cohort in the future study is needed. Based on our results, it should be noted that liver histopathologic inflammation evaluation through invasive or noninvasive methods is necessary to assess the influence of the same HPCV on serum HBV DNA and HBsAg in the natural history of CHB. Furthermore, effective antiviral-therapy should be applied according to liver pathological inflammation diagnosis, even if serum HBV DNA and (or) HBsAg detected at low levels, and the clinicians should strengthen monitoring and follow-up to these CHB patients whose serum HBV DNA levels and (or) HBsAg titers seemed "declining" naturally. Taken together, this study provided a better understanding of the change of serum HBV DNA levels and HBsAg titers released by the same HPCV in various inflammation stages in the natural history of $\mathrm{CHB}$, and it might be helpful to understand and monitor the progress of $\mathrm{CHB}$.

\section{Acknowledgments}

Funding: The manuscript was supported by Youth Program of National Natural Science Foundation of China Science Fund Project 81702375; Young Teacher Training Project of Sun Yat-sen University 19ykpy32; Youth Program of Hengrui Hepatobiliary and Pancreatic Cancer Research Fund CXPJJH11800001-20183331.

\section{Footnote}

Reporting Checklist: The authors have completed the STROBE reporting checklist. Available at http://dx.doi. org/10.21037/apm-20-635
Data Sharing Statement: Available at http://dx.doi. org/10.21037/apm-20-635

Conflicts of Interest: All authors have completed the ICMJE uniform disclosure form (available at http://dx.doi. org/10.21037/apm-20-635). The authors have no conflicts of interest to declare.

Etbical Statement: The authors are accountable for all aspects of the work in ensuring that questions related to the accuracy or integrity of any part of the work are appropriately investigated and resolved. This work was approved by the local ethical committee of the Third Affiliated Hospital of Sun Yat-sen University (the ethical number: [2018]02-429-01). All 254 CHB patients in our retrospective investigation had been informed of possible complications with liver biopsies clearly before the invasive operation, and informed consent forms had been signed. This study has been performed in accordance with the principles of Declaration of Helsinki (as revised in 2013).

Open Access Statement: This is an Open Access article distributed in accordance with the Creative Commons Attribution-NonCommercial-NoDerivs 4.0 International License (CC BY-NC-ND 4.0), which permits the noncommercial replication and distribution of the article with the strict proviso that no changes or edits are made and the original work is properly cited (including links to both the formal publication through the relevant DOI and the license). See: https://creativecommons.org/licenses/by-nc-nd/4.0/.

\section{References}

1. Lanini S, Pisapia R, Capobianchi MR, et al. Global epidemiology of viral hepatitis and national needs for complete control. Expert Rev Anti Infect Ther 2018;16:625-39.

2. Pan CQ, Zhang JX. Natural History and Clinical Consequences of Hepatitis B Virus Infection. Int J Med Sci 2005;2:36-40.

3. Ganem D, Prince AM. Hepatitis B virus infection-natural history and clinical consequences. $\mathrm{N}$ Engl J Med 2004;350:1118-29.

4. Yuen MF, Sablon E, Hui CK, et al. Prognostic factors in severe exacerbation of chronic hepatitis B. Clin Infect Dis 2003;36:979-84.

5. Schacherer D, Schuh C, Strauch U, et al. Improvement in the routine diagnostic assessment of the liver by high- 
resolution sonography: an analysis of 999 cases. Scand J Gastroenterol 2007;42:366-73.

6. Zhu HY, Zhang XS. Relationship between HBV DNA load and levels of serum HBsAg in patients with chronic hepatitis B. Eur Rev Med Pharmacol Sci 2016;20:2061-4.

7. Xiang KH, Michailidis E, Ding H, et al. Effects of amino acid substitutions in hepatitis $\mathrm{B}$ virus surface protein on virion secretion, antigenicity, HBsAg and viral DNA. J Hepatol 2017;66:288-96.

8. Liu C, Wang L, Xie H, et al. The relationship between serum hepatitis B virus DNA level and liver histology in patients with chronic HBV infection. PLoS One 2018; 13:e0206060.

9. Zhang P, Du HB, Tong GD, et al. Serum hepatitis $B$ surface antigen correlates with fibrosis and necroinflammation: A multicentre perspective in China. J Viral Hepat 2018;25:1017-25.

10. Xie SB, Yao JL, Zheng SS, et al. The levels of serum fibrosis marks and morphometric quantitative measurement of hepatic fibrosis. Hepatobiliary Pancreat Dis Int 2002;1:202-6.

11. Ke WM, Xie SB, Li XJ, et al. There were no differences in serum HBV DNA level between HBeAg-positive and $\mathrm{HBeAg-negative} \mathrm{chronic} \mathrm{hepatitis} \mathrm{B} \mathrm{with} \mathrm{same} \mathrm{liver}$ histological necroinflammation grade but differences among grades 1, 2, 3 and 4 apportioned by the same hepatic parenchyma cell volume. J Viral Hepat 2011;18:637-45

12. Yuen MF, Gane EJ, Kim DJ, et al. Antiviral Activity, Safety, and Pharmacokinetics of Capsid Assembly Modulator NVR 3-778 in Patients with Chronic HBV Infection. Gastroenterology 2019;156:1392-1403.e7.

13. Li MR, Xi HL, Wang QH, et al. Kinetics and prediction of HBsAg loss during long-term therapy with nucleos(t) ide analogues of different potency in patients with chronic hepatitis B. PLoS One 2014;9:e98476.

14. Li J, Sun X, Fang J, Wang C, et al. Analysis of intrahepatic total HBV DNA, cccDNA and serum HBsAg level in Chronic Hepatitis B patients with undetectable serum

Cite this article as: Tan $\mathrm{L}, \mathrm{Wu} Z \mathrm{ZQ}$, Zhao C, Chen SR, Wang PP, Gao ZL, Xie DY, Hu KP, Mo ZS. A perspective of the relationship of serum HBV DNA and HBsAg apportioned by the same hepatic parenchyma cell volume with inflammation in the natural history of chronic hepatitis B. Ann Palliat Med 2021;10(2):1388-1395. doi: 10.21037/apm-20-635
HBV DNA during oral antiviral therapy. Clin Res Hepatol Gastroenterol 2017;41:635-43.

15. Huang H, Wang J, Li W, et al. Serum HBV DNA plus RNA shows superiority in reflecting the activity of intrahepatic cccDNA in treatment-naive $\mathrm{HBV}$-infected individuals. J Clin Virol 2018;99-100:71-8.

16. Chuaypen N, Sriprapun M, Praianantathavorn K, et al. Kinetics of serum HBsAg and intrahepatic cccDNA during pegylated interferon therapy in patients with $\mathrm{HBeAg}$ positive and HBeAg-negative chronic hepatitis B. J Med Virol 2017;89:130-8.

17. Li MR, Zheng HW, Ma SM, et al. Correlations between serum hepatitis B surface antigen and hepatitis B core antibody titers and liver fibrosis in treatment-naive $\mathrm{CHB}$ patients. J Chin Med Assoc 2018;81:1052-9.

18. Goyal SK, Jain AK, Dixit VK, et al. HBsAg Level as Predictor of Liver Fibrosis in HBeAg Positive Patients With Chronic Hepatitis B Virus Infection. J Clin Exp Hepatol 2015;5:213-20.

19. Xie Q, Hu X, Zhang Y, et al. Decreasing hepatitis B viral load is associated with a risk of significant liver fibrosis in hepatitis B e antigen positive chronic hepatitis B. J Med Virol 2014;86:1828-37.

20. Gao Y, Zou G, Ye J, et al. Relationship between hepatitis B surface antigen, HBV DNA quantity and liver fibrosis severity. Zhonghua Gan Zang Bing Za Zhi 2015;23:254-7.

21. Ahmed FA, Bajaifar MS, Ahmed MA, et al. Quantitative HBsAg levels do not identify hepatic fibrosis in $\mathrm{HBeAg}-$ negative chronic hepatitis B patients. Saudi J Gastroenterol 2019;25:286-92.

22. Xiao CH, Sun HX, Zhang K, et al. Comparative study on the clinical characteristics of $\mathrm{HBV}$ infection patients with different pathologic inflammation grade. Zhonghua Shi Yan He Lin Chuang Bing Du Xue Za Zhi 2013;27:270-2.

23. Ke WM, Xie SB, et al. Decline of serum HBV DNA and no change apportioned by the same hepatic parenchyma cell volume from hepatic fibrosis stage 1 to stage 4 during the natural history of chronic hepatitis B. Intervirology 2008;51:235-40. 